
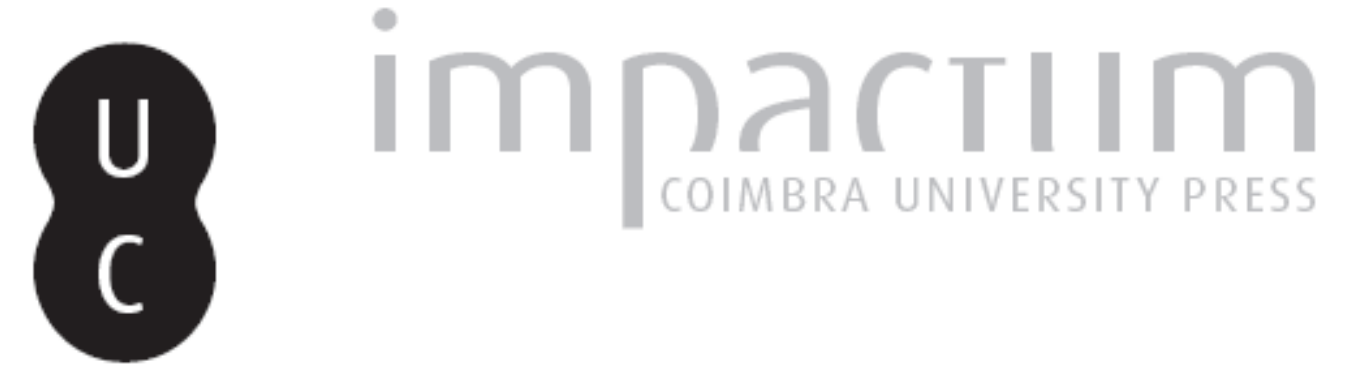

\title{
A memória histórica enquanto instrumento de controlo durante o Estado Novo: o exemplo do antissemitismo
}

Autor(es): $\quad$ Nunes, João Paulo Avelãs

Publicado por: Imprensa da Universidade de Coimbra

URL persistente:

URI:http://hdl.handle.net/10316.2/40212

DOI:

DOI:https://doi.org/10.14195/2183-8925_34_6

Accessed : $\quad$ 26-Apr-2023 10:00:21

A navegação consulta e descarregamento dos títulos inseridos nas Bibliotecas Digitais UC Digitalis, UC Pombalina e UC Impactum, pressupõem a aceitação plena e sem reservas dos Termos e Condições de Uso destas Bibliotecas Digitais, disponíveis em https://digitalis.uc.pt/pt-pt/termos.

Conforme exposto nos referidos Termos e Condições de Uso, o descarregamento de títulos de acesso restrito requer uma licença válida de autorização devendo o utilizador aceder ao(s) documento(s) a partir de um endereço de IP da instituição detentora da supramencionada licença.

Ao utilizador é apenas permitido o descarregamento para uso pessoal, pelo que o emprego do(s) título(s) descarregado(s) para outro fim, designadamente comercial, carece de autorização do respetivo autor ou editor da obra.

Na medida em que todas as obras da UC Digitalis se encontram protegidas pelo Código do Direito de Autor e Direitos Conexos e demais legislação aplicável, toda a cópia, parcial ou total, deste documento, nos casos em que é legalmente admitida, deverá conter ou fazer-se acompanhar por este aviso.





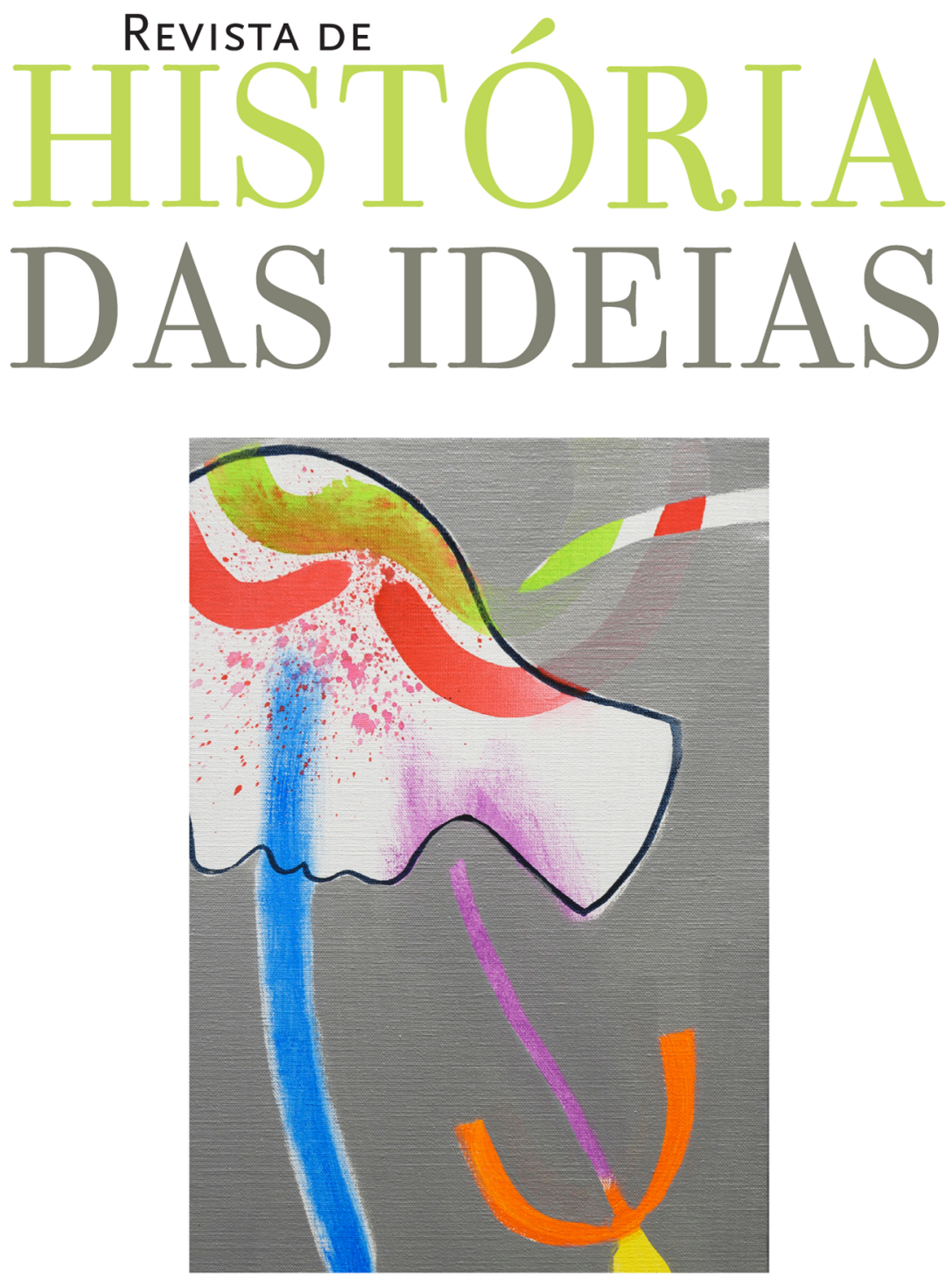

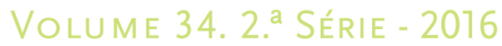




\section{A MEMÓRIA HISTÓRICA ENQUANTO INSTRUMENTO DE CONTROLO DURANTE O ESTADO NOVO. O EXEMPLO DO ANTISSEMITISMO ${ }^{(1)}$ HISTORICAL MEMORY AS A CONTROLLING INSTRUIMENT DUIRING THE ESTADO NOVO PERIOD. THE ANTI-SEMITISM EXAMPLE}

\section{Jõ̃o Paulo Avelãs Nunes}

jpavelas@fl.uc.pt

FLUC e CEIS20/UC

Texto recebido em / Text submitted on: 31/03/2016

Texto aprovado em / Text approved on: 14/07/2016

\section{Resumo:}

Viso analisar as modalidades e as consequências da utilização da historiografia e da memória histórica enquanto instrumentos de controlo. Considerar-se-ão vetores de estruturação da identidade histórico-cultural que o Estado Novo tentou impor e dar-se-á atenção à problemática do antissemitismo. Procurar-se-á correlacionar estas questões com o debate acerca da natureza da ditadura lusa.

Parto do pressuposto de que, devido à personalidade dos dirigentes e aos equilíbrios internos do regime, às características do país e do respetivo contexto internacional, também na regionalidade cultural o Estado Novo optou por impor uma solução formalmente moderada. Tratar-se-ia, na aparência, de uma memória histórica pouco ideológica, escassamente diferenciada das narrativas

(1) Texto da comunicação proferida no âmbito do Colóquio Internacional «O controlo dos corpos e das mentes. Estratégias de dominação dos regimes fascistas e autoritários» (Rio de Janeiro, LEER/USP e Arquivo Nacional, 21/10/15). 
antes dominantes e não marcada pelo antissemitismo. Foi consubstanciada através do historicismo neometódico.

Defendo, ainda, que, partindo de uma Ditadura Militar, opondo-se à Primeira República e, quer a uma solução democrática, quer a um figurino «socialista», o Estado Novo configurou-se enquanto fascismo. Essa mesma classificação é válida apesar de António de Oliveira Salazar e de a maioria dos dirigentes intermédios do regime terem proclamado a existência de limites religiosos, éticos e legais no que concerne ao exercício da violência e à operacionalização de modalidades de enquadramento da «sociedade civil».

\title{
Palavras-chave:
}

Estado Novo, memória histórica, antissemitismo, darwinismo social, nacionalismo.

\begin{abstract}
:
I aim to outline the consequences of the use of historiography and historical memory as mind-controlling instruments. It will address aspects of the historicalcultural identity that the Estado Novo tried to impose, and pay attention to the problem of anti-Semitism. We will seek to correlate these issues with the discussion about the nature of the Portuguese dictatorship.

I propose that, due to the personality of the leaders and to the balances of the regime, to the charactersitics of the country and of the international context, also in the cultural sphere did the Estado Novo chose to impose formally moderate solutions. This would be a historical memory short of ideology that could scarcely be distinguished from the prior dominating narratives not marked by anti-Semitism. It was embodied through neo-methodical historicism.

It is further argued that from a military dictatorship, against the First Republic, against a democratic solution or «socialist» model, the Estado Novo took shape as fascism. This very classification is valid despite António de Oliveira Salazar and the intermediate leaders of the regime having claimed that there were religious, ethical and legal limits to the exercise of violence and to the operationalisation of modalities of controling the «civil society».
\end{abstract}

\section{Keywords:}

Estado Novo, historical memory, anti-semitism, social darwinism, nationalism.

\section{Introdução}

Viso, neste artigo, analisar as modalidades concretas e as consequências da utilização da historiografia e da memória histórica enquanto 
instrumentos de controlo das mentes pelo Estado Novo português. Considerar-se-ão diversos vetores de estruturação da identidade histórico-cultural que o salazarismo tentou impor e dar-se-á particular atenção à problemática do antissemitismo. Procurar-se-á, ainda, correlacionar estas questões com o debate acerca da natureza da ditadura lusa: regime autoritário ou totalitário, conservador e católico ou fascista? O caso português será comparado com outros exemplos nacionais.

Parto do pressuposto de que, devido à personalidade dos principais dirigentes e aos equilíbrios internos do regime, às características do país e do respetivo contexto internacional, tal como em outros âmbitos, também na regionalidade cultural o Estado Novo optou por impor uma solução formalmente moderada. Tratar-se-ia, na aparência, de uma memória histórica pouco ideológica, escassamente diferenciada das narrativas antes dominantes e não marcada pelo antissemitismo. Foi consubstanciada através do historicismo neo-metódico, hegemónico nas décadas de 1930 a 1960 e prevalecente até ao final da ditadura.

Defendo, ainda, que, partindo de uma Ditadura Militar (autoritarismo de direita), opondo-se radicalmente à Primeira República demoliberal com vetores de autoritarismo e, quer a uma possível solução democrática, quer a um eventual figurino socialista (social-democrata, anarquista e/ ou comunista), o Estado Novo configurou-se enquanto fascismo, ou seja, como ditadura totalitária de direita. Essa mesma classificação é válida apesar de António de Oliveira Salazar e de a maioria dos dirigentes intermédios do regime terem proclamado a existência de limites religiosos, éticos e legais no que concerne ao exercício da violência e à operacionalização de modalidades de enquadramento da «sociedade civil».

No contexto de um regime de tipo fascista e tendencialmente totalitário, a identidade histórico-cultural descrita como indiscutível teria, assim, assumido diferenças significativas face ao sucedido em etapas anteriores. Resultaria, quer de um esforço sistemático de imposição por parte dos Órgãos de Soberania, do aparelho de Estado e das organizações oficiosas da ditadura, quer da repressão - punitiva e preventiva exercida sobre os defensores das propostas alternativas. Para além de «o passado» ser apresentado como exemplo (positivo ou negativo) e como fator de legitimação da ditadura, a «portugalidade» decorreria somente de especificidades rácicas e geográficas, da integração na «Civilização Ocidental» e da ligação exclusiva ao catolicismo, da concretização de um organicismo hierárquico e de um imperativo colonizador, do predomínio 
de uma ruralidade frugal e do respeito pelas chefias naturais (no âmbito do Estado-Nação, das instituições e organizações, da família).

Através do discurso historiográfico e dos outros vetores de estruturação da memória histórica - o ensino e a divulgação científica, o património cultural e a museologia, as comemorações históricopatrióticas e a propaganda (política, sindical e religiosa), a comunicação social e a publicidade, a arquitetura e o urbanismo, a produção artística em geral e a estatuária em particular, a toponímia e a numismática, as organizações da «sociedade civil» e os contextos familiares ou vicinais, etc. -, o salazarismo fundamentou, por um lado, a recusa em adotar uma postura explícita e ativamente antissemita. Por outro lado, terá recorrido à rememoração e ao elogio do anti-judaísmo dominante na época moderna para legitimar um antissemitismo preventivo e de cariz mais político-administrativo do que sociocultural.

Identificada, ao longo da Idade Média, a ameaça associada à presença em «terras lusas» de um grande número de judeus - recusa da «religião verdadeira» e da integração na "comunidade nacional», características rácicas não europeias e ambição de domínio sobre os "cristãos e ocidentais», deformações físicas e culturais -, durante a Idade Moderna o Estado, a Igreja Católica e a «sociedade civil» convergiram para aplicar uma mundividência antissemita. Conseguiu-se extirpar o problema em causa através da expulsão e da conversão forçada dos judeus, da repressão de práticas judaicas clandestinas, da segregação entre «cristãos velhos» $\mathrm{e}$ «cristãos novos». Na Idade Contemporânea, mau grado a ligação entre os judeus e os aspetos negativos da modernização introduzidos com o «interregno pombalino», com a Revolução Liberal de 1820 e com a Revolução Republicana de 1910 - racionalismo e agnosticismo, ateísmo e internacionalismo, materialismo e individualismo ou igualitarismo -, Portugal teria conseguido evitar a entrada de «quantitativos excessivos» de judeus, promover a integração parcial e a neutralização dos judeus presentes em «solo pátrio», consolidar a estratégia global de regeneração consubstanciada pelo Estado Novo(2).

(2) Cf., nomeadamente, Fernando Catroga, Memória, história e historiografia, Coimbra, Quarteto Editora, 2001; Manuel Loff, As duas ditaduras ibéricas na nova ordem eurofascista, Florença, 2004, vol. 3 (policop.); Jorge Martins, «O moderno anti-semitismo em Portugal», Vária Escrita, 11 (2004), p. 291-336; Elvira de Azevedo Mea e Inácio Steinhardt, Ben-Rosh. Biografia do Capitão Barros Basto, o «apóstolo dos marranos», Porto, Edições Afrontamento, 1997; Avraham Milgram, Portugal, Salazar e os judeus, Lisboa, Gradiva, 2010; Lúcia Liba 
Face à relativa exiguidade da investigação monográfica já realizada sobre a presença ou a ausência de anti-judaísmo, antissemitismo e filosemitismo na historiografia e na memória histórica produzida e divulgada em Portugal nas primeiras décadas do Estado Novo, optei por elaborar este texto partindo de sondagens não aleatórias no universo de documentação potencialmente relevante. Embora pense que o peso do antissemitismo na produção e na divulgação de discursos historiográficos e outros elementos configuradores da memória histórica oficiosa do salazarismo foi bastante maior do que até agora tem sido reconhecido - sob a forma de um antissemitismo difuso e da apologia sistemática do anti-judaísmo vigente entre nós na Época Moderna -, não pude realizar, nem o rastreio e a análise integrais dos núcleos documentais existentes, nem sequer a delimitação e o estudo de amostras proporcionalmente representativas.

\section{Estado Novo e ideologia}

Devido à presença endémica de condicionalismos estruturais e à intervenção de vetores conjunturais ou pontuais, tanto no salazarismo como, de forma acrescida, durante o marcelismo, o nível de radicalismo ideológico patenteado foi inferior, tanto ao grau de violência da sua própria praxis político-administrativa e social, como à explicitude ideológica verificada em outros países com regimes fascistas. Importante será, pois, averiguar se a aparente moderação ideológica do Estado Novo não encobre uma sistematicidade e uma firmeza bem maiores do que as respetivas elites proclamaram e do que por vezes se tem reconstituído e analisado ${ }^{(3)}$.

Mucznik e outros (coord.), Dicionário do judaísmo português, Lisboa, Editorial Presença, 2009; João Paulo Avelãs Nunes, «A memória histórica enquanto tecnologia. Estado Novo, desenvolvimento e democracia», in Irene Flunser Pimentel e Maria Inácia Rezola (ed.), Democracia, ditadura: memória e justiça política, Lisboa, Edições Tinta-da-China, 2013, p. 363384; João Paulo Avelãs Nunes, «Darwinismo social e antisemitismo: o caso português», Cultura, Espaço \& Memória, 5 (2014), p. 117-132; Livia Parnes, Présences juïves dans le Portugal contemporain (1820-1939), 2 vols., Paris, 2002 (policop.); Ana Leonor Pereira, Darwin em Portugal: filosofia, história, engenharia social (1865-1914), Coimbra, Livraria Almedina, 2001; Irene Flunser Pimentel, Judeus em Portugal durante a II Guerra Mundial, Lisboa, A Esfera dos Livros, 2008, $3^{\text {a }}$ ed.; Irene Flunser Pimentel e Cláudia Ninhos, Salazar, Portugal e o Holocausto, Lisboa, Temas e Debates, 2013; Ansgar Schaefer, Portugal e os refugiados judeus provenientes do território alemão, Coimbra, IUC, 2014.

(3) Cf., entre outros, Susana Chalante, «O discurso do Estado salazarista perante o 'indesejável' (1933-1939)», Análise Social, 198 (2011), p. 41-63; Ernesto Castro Leal, Nação e 
Quanto aos condicionalismos estruturais que podem ter influenciado no sentido da adoção de uma estratégia de moderação formal, também no plano ideológico, por parte do Estado Novo, referem-se, habitualmente, a não substituível integração de Portugal na «zona de influência» do Reino Unido no âmbito do sistema de relações internacionais (garante da independência, da manutenção de territórios coloniais, do fornecimento de capitais e de bens/serviços essenciais); os baixos níveis de envolvimento cívico e de participação política por parte da maioria da população; o predomínio de um nacionalismo defensivo e não irredentista nos planos metropolitano e colonial; a inexistência de grandes organizações políticas de massas de extrema-direita.

Em relação aos vetores conjunturais ou pontuais geradores de contenção ideológica aparente, citam-se, frequentemente, a postura não-beligerante ou, mesmo, neutralista assumida pelos setores da direita lusa durante a Primeira Grande Guerra; o peso na "sociedade civil" portuguesa de uma Igreja Católica e de uma «ação católica» que se pautaram, sobretudo, pela democracia-cristã conservadora; as personalidades e os percursos biográficos, entre outros, de Óscar Fragoso Carmona, António de Oliveira Salazar e Manuel Gonçalves

nacionalismo. A Cruzada Nacional D. Nuno Álvares Pereira e as origens do Estado Novo (19181938), Lisboa, Edições Cosmos, 1999; Manuel Loff, O novo século é fascista! O Mundo visto por Salazar e Franco (1936-1945), Porto, Campo das Letras, 2008; Riccardo Marchi, As direitas radicais em Portugal durante o Estado Novo (1945-1974), Lisboa, 2007 (policop.); João Paulo Avelãs Nunes, «Ideologia e história no Estado Novo (1933-1949)», Vértice, II série, 56, set. / out. 1993, p. 13-23; João Paulo Avelãs Nunes, O CADC de Coimbra, a democracia cristã e os inícios do Estado Novo (1905-1934), Coimbra, FLUC, 1993; João Paulo Avelãs Nunes, "As organizações de juventude e a memória histórica do Estado Novo (1934-1949)”, Anais/ História [UAL] (1996/1997), p. 235-275; João Paulo Avelãs Nunes, «Tipologias de regimes políticos. Para uma leitura neo-moderna do Estado Novo e do Nuevo Estado», População e Sociedade, 8 (2002), p. 73-101; João Paulo Avelãs Nunes, «Funções da legislação no Estado Novo português (1926-1974)», in Nilson Borges Filho e Fernando Filgueiras (ed.), Estado, direito e ética. Ensaios sobre questões da nossa época, Juiz de Fora, Granbery Edições, 2007, p. 31-50; Jorge Ramos do O, Os anos de Ferro. O dispositivo cultural durante a "Política do Espírito" (1933-1939), Lisboa, Editorial Estampa, 1999; António Costa Pinto, A Acção Escolar Vanguarda (1933-1936). A juventude nacionalista nos primórdios do Estado Novo, Lisboa, História Critica, 1980; António Costa Pinto, Os Camisas Azuis. Ideologia, elites e movimentos fascistas em Portugal (1914-1945), Lisboa, Editorial Estampa, 1994; Gabriel de Jesus Pita, A Igreja Católica perante o nacionalismo português do Estado Novo. A revista Lumen (1937-1945), 2 vols., Lisboa, 1995 (policop.); Fernando Rosas, Salazar e o poder: a arte de saber durar, Lisboa, Edições tinta-da-china, 2015; Luís Reis Torgal, Estados novos, Estado Novo: ensaios de história política e cultural, 2 vols., Coimbra, IUC, 2010; Miguel Dias Santos, A contra-revolução na I República (1910-1919), Coimbra, IUC, 2010. 
Cerejeira; as fraturas potenciais que colocavam em risco a unidade das elites apoiantes da ditadura (republicanos versus monárquicos, católicos versus maçons, conservadores e tradicionalistas versus modernizadores, moderados versus radicais, etc.).

Considero que o salazarismo optou por construir uma estrutura ideológica formalmente defensiva ou de mera continuidade mas na realidade totalizante e, quer laudatória do regime e do respetivo Chefe, quer absolutamente condenatória das alternativas (das experiências passadas e de eventuais soluções futuras). Para além da consolidação de um amplo argumentário simbólico, ocorreu a implantação de um multifacetado aparelho de controlo e de repressão, a concretização de sucessivas iniciativas de mobilização e de comemoração. Lembra-se, ainda, que parte substancial da população portuguesa não era alvo deste esforço, uma vez que só conheceria uma vivência pré-cívica, que estaria ainda enquadrada através das modalidades tradicionais de tutela e de neutralização sociopolítica.

Fruto, até à década de 1950, da prevalência dos setores conservadores sobre as componentes modernizadoras e tradicionalistas, o Estado Novo apresentou-se como tentativa bem sucedida de «regeneração nacional» por poder aplicar conhecimento acumulado sobre fatores e períodos de «apogeu» e de "decadência», acerca da forma como Portugal se foi integrando nos sistemas de relações internacionais. Esta aparente moderação e indiscutibilidade da mensagem ideológica nuclear do regime ampliava a credibilidade, tanto dos elogios às respetivas propostas e elites - supostamente abertas a todos os «contributos patrióticos»-, como da deslegitimação e diabolização das oposições (apresentados como fatores patológicos de desagregação induzidos a partir do exterior).

A própria natureza simultaneamente omnipresente e autolimitada, negociada e sincrética do sistema de propaganda e de repressão implantado acabou por reforçar aquela imagem de contenção e de adaptabilidade. Deparamos, por um lado, com a existência de estruturas especializadas e generalistas do aparelho de Estado (Secretariado de Propaganda Nacional, Ministério da Instrução Pública - Ministério da Educação Nacional desde 1936 - e Serviços de Censura; Subsecretaria de Estado das Corporações e Previdência Social, Ministério das Obras Públicas e Comunicações, Polícia de Vigilância e de Defesa do Estado, etc.); de estruturas oficiosas de cariz generalista - União Nacional e Legião Portuguesa, Ação Escolar Vanguarda e, depois, Mocidade 
Portuguesa e Mocidade Portuguesa Feminina, Obra das Mães pela Educação Nacional e «Organização Corporativa» -; de organizações generalistas da «sociedade civil» (Igreja e Acção Católica Portuguesa, associações empresariais transversais e clubes desportivos, etc.). Por outro lado, observamos a focalização das atividades de propaganda nas zonas urbanas da «Metrópole», das «Ilhas Adjacentes» e das «Colónias»; nas áreas rurais do Ribatejo e do Alentejo.

Identifica-se, também, a presença de valores e de estéticas tanto tradicionalistas e conservadores como modernizadores, assumindo os mesmos, no entanto, configurações e pesos relativos diferentes de acordo com os protagonistas e com as conjunturas em causa (antes e depois da Guerra Civil de Espanha, durante a Segunda Guerra Mundial, no início da «Guerra Fria»). Elenca-se, finalmente, a realização de múltiplos eventos públicos - por norma centrados na figura de António de Oliveira Salazar - de natureza militar e política, corporativa e religiosa, históricopatriótica e desportiva.

\section{Estado Novo, historiografia e «identidade nacional»}

Edificado como resposta aos impasses da Ditadura Militar e por contraposição, quer à Primeira República, quer a potenciais figurinos democráticos ou comunistas, o Estado Novo configurou e impôs o historicismo neometódico como narrativa oficiosa acerca da evolução do país ao longo de séculos, enquanto vetor fundamental da leitura do regime sobre as implicações «do passado» na atualidade e perante o futuro. Em termos deontológicos e epistemológicos, teóricos e metodológicos, aquela corrente científico-ideológica apresentou-se na qualidade de guia imperativo de orientação para a compreensão da e para a intervenção na realidade nacional porque súmula do catolicismo e da ética, da filosofia e da ciência, do senso comum e do «instinto da Raça»; como misto de subjetivismo providencialista e de objetivismo neo-empirista; enquanto recusa da validade dos conceitos teóricos em historiografia, substituídos pela autossuficiência de uma metodologia baseada na verificação da autenticidade e na exegese de documentação escrita narrativa, iconográfica ou arqueológica.

Os cultores do historicismo neometódico procuraram, assim, substituir ou impedir a implantação no Portugal chefiado por António 
de Oliveira Salazar de conceções historiográficas caracterizadas como demasiado explícitas quanto à sua militância em favor da «Revolução Nacional» (irracionalismo providencialista), como eventualmente promotoras de mundividências «reviralhistas» (escola metódica, historicismo romântico, positivismo, idealismo crítico, história institucional e política clássica, história económica e social clássica) ou como elementos de legitimação de ideologias oposicionistas (marxismo, história nova, história estruturalista). Nas duas primeiras décadas de ditadura, mesmo alguns estudiosos da história apoiantes do novo regime foram afastados de funções que desempenhavam em instituições de ensino superior e de apoio à investigação por continuarem a defender as virtualidades de perspetivas historiográficas - irracionalismo providencialista, positivismo, idealismo crítico, história institucional e política clássica, história económica e social clássica - diferentes do emergente historicismo neo-metódico ${ }^{(4)}$.

Pelo menos desde 1930, nas Faculdades de Letras enas Escolas Normais Superiores das Universidades de Lisboa e de Coimbra, a investigação e o ensino da história atribuíram preferência à história de Portugal, às regionalidades política e militar, à intervenção das elites e a manifestações da cultura erudita. Deixaram, no essencial, de abarcar o período contemporâneo e a regionalidade económica e social, a história das mentalidades e das «temáticas marginais» (mulheres e pobres, escravatura e heresias, culturas populares e cultura de massas, etc.), as ligações interdisciplinares à sociologia e à economia. Verificou-se, ainda, a quase extinção da área de saber tecnológico da didática da História, transformada na mera afirmação dos pressupostos e dos objetivos do sistema de ensino do salazarismo (seleção de professores tendo em conta critérios também políticos, presença de

(4) Cf., nomeadamente, Fernando Catroga, Memória, história e historiografia..., cit., p. 6; Marc Ferro, L'histoire sous surveillance. Science et conscience de l'histoire, Paris, Calman-Lévy, 1985; Sérgio Campos Matos, História, mitologia e imaginário nacional. A história no curso dos liceus (1895-1939), Lisboa, Livros Horizonte, 1990; João Paulo Avelãs Nunes, A história económica e social na FLUC (1911-1974). O historicismo neo-metódico: ascensão e queda de um paradigma historiográfico, Lisboa, IIE, 1995; João Paulo Avelãs Nunes, «O Estado, a historiografia e outras ciências / tecnologias sociais», in João Paulo Avelãs Nunes e Américo Freire (coord.), Historiografias portuguesa e brasileira no século XX. Olhares cruzados, Coimbra, IUC, 2013, p. 53-79; João Paulo Avelãs Nunes, «A memória histórica enquanto tecnologia..., cit., p. 6; Luís Reis Torgal, História e ideologia, Coimbra, Livraria Minerva, 1989; Luís Reis Torgal e outros, História da história em Portugal (séculos XIX-XX), Lisboa, Círculo de Leitores, 1996; Enzo Traverso, O passado, modos de usar (trad. do francês), Lisboa, Edições Unipop, 2012. 
vetores ideológicos explícitos nos programas, manuais únicos obrigatórios, pedagogia diretiva e baseada na memorização).

Segundo o historicismo neo-metódico, Portugal nasceu como EstadoNação coerente na primeira metade do século XII, resultado de um processo de fusão de povos do sul e do centro da Europa, de adaptação dessas populações às características geoclimáticas do ocidente da Península Ibérica, de integração na «Civilização Ocidental» por intermédio da «Romanização», de consolidação das diferenças relativamente aos outros povos hispânicos durante a Antiguidade Tardia e na Alta Idade Média. Teria mantido desde a Idade Média um conjunto de características fundamentais (identitárias), nomeadamente, a unidade nacional e a estabilidade territorial, o equilíbrio entre Governo central e poderes locais, o catolicismo e a organização corporativa, a hierarquização social e a convergência entre «elites»e «classes populares», o predomínio da ruralidade e a «responsabilidade colonizadora» («civilizadora e cristianizadora»).

Depois de um processo inicial de conquista territorial e de reforço da «coesão da Metrópole» - perante Leão e Castela, face aos Estados dos «invasores islâmicos», relativamente às comunidades de muçulmanos e de judeus -, ter-se-ia seguido um esforço de afirmação internacional enquanto «potência ocidental e cristã» (povoamento das Ilhas Adjacentes e construção de um Império pluricontinental). Os períodos de apogeu ocorreram sempre que, sob a «tutela espiritual» da Santa Sé e com o apoio da Inglaterra, os «Chefes da Pátria» respeitaram e defenderam as características e os interesses «da Nação». As etapas de decadência resultaram de agressões por parte de outros países - Espanha, França, Holanda, Alemanha -; da infiltração de ideários e comportamentos, organizações e soluções inorgânicos ou malignos através da ação de «estrangeirados».

Com algumas exceções - miguelismo, democracia-cristã conservadora, «Campanhas de Pacificação» em Angola e Moçambique, autoritarismo monárquico, Integralismo Lusitano, sidonismo -, até ao 28 de maio de 1926 a história contemporânea de Portugal consistiria numa sucessão de lideranças e de práticas mais ou menos disfuncionais, decorrentes do aumento da influência de ideologias alheias e/ ou patológicas. ADitadura Militar, António de Oliveira Salazar e o Estado Novo representariam, em sentido inverso, «a regeneração nacional» através da reconstituição e da revalorização das "verdadeiras tradições pátrias», da introdução de elementos de modernização compatível, do extirpar das conceções e das atuações desagregadoras. 


\section{Estado Novo e memória histórica}

Uma vez argumentada a legitimidade exclusiva da narrativa oficiosa sobre a história de Portugal (por intermédio do historicismo neometódico), depois de fixado um perfil coerente de «identidade histórico-cultural nacional» e de vinculação do presente e do futuro ao passado - através da depuração e da reformulação dos mitemas do «nacionalismo luso» -, uma vez anuladas as dissonâncias existentes na base de apoio da ditadura e de afirmado o caráter erróneo das leituras divergentes, o salazarismo empenhou-se na disseminação da nova ortodoxia. Procurou mobilizar para o efeito, de modo sistémico, a totalidade dos instrumentos complementares de consolidação de uma memória histórica única mas de geometria variável, isto é, ajustável às necessidades específicas das elites, do grupo socioprofissional dos historiadores e professores de História, dos outros segmentos das «classes médias», dos jovens que frequentavam o ensino médio e superior, «das crianças e do povo» ${ }^{(5)}$.

No âmbito do ensino não superior e da divulgação científica, o discurso sobre história foi semelhante ao elaborado e reproduzido nas Faculdades de Letras, ocorrendo, no entanto, alguma diferenciação. Concedeu-se maior peso à "história geral" (quase exclusivamente história da Europa e, nesta, de Leão e Castela/Espanha, França, Inglaterra/Grã-Bretanha) e caracterizou-se a época contemporânea, apresentada como período globalmente negativo porque marcado pelos «princípios funestos» da Revolução Francesa: racionalismo e filo-semitismo, individualismo e materialismo, plutocracia ou igualitarismo, liberalismo ou democracia e socialismos, laicismo e agnosticismo ou ateísmo, nacionalismo pagão ou internacionalismo, capitalismo ou coletivismo.

(5) Cf., entre outros, Fernando Catroga, Memória, história e historiografia..., cit., p. 6 e 10; Marc Ferro, L'histoire sous surveillance..., cit., p. 10; Sérgio Campos Matos, História, mitologia e imaginário nacional..., cit., p. 10; João Paulo Avelãs Nunes, «Ideologia e história no Estado Novo..., cit., p. 6; João Paulo Avelãs Nunes, «As organizações de juventude e a memória histórica do Estado Novo..., cit., p. 6; João Paulo Avelãs Nunes, «O Estado, a historiografia e outras ciências / tecnologias sociais..., cit., p. 10; Jorge Ramos do Ó, Os anos de Ferro..., cit., p. 7; António Costa Pinto e Nuno Gonçalo Monteiro (dir.), História Contemporânea de Portugal (1808-2010), 5 vols., Lisboa, Fundação MAPFRE e Penguin Random House Grupo Editorial Unipessoal, Lda., 2013-2015; Fernando Rosas (coord.), O Estado Novo (1926-1974), José Mattoso (dir.), História de Portugal, Lisboa, Círculo de Leitores, 1994, vol. 7; Luís Reis Torgal, História e ideologia..., cit., p. 10; Luís Reis Torgal e outros, História da história em Portugal..., cit., p. 10. 
Tratando-se de tecnologias de grande longevidade, muito exigentes em termos de investimento inicial e de cariz eminentemente público, de particular eficácia quanto à capacidade de influenciar transversalmente nacionais e visitantes ou observadores estrangeiros, a arquitetura e o urbanismo, o património cultural e a museologia mereceram atenção redobrada por parte do salazarismo. Para além de se estabelecer um perfil de remodelação indiscutivelmente associável ao regime - misto de modernismo e de neoclassicismo monumentalista, de historicismo e de regionalismo -, aumentou-se o número, a visibilidade e os tipos de utilização dados às "zonas históricas», aos monumentos e aos outros edifícios intervencionados (reutilizados, restaurados e construídos) ou construídos de raiz.

Quanto às épocas, correntes estéticas e funções sociais adotadas como modelo inspirador da modernização nacionalista e historicista do espaço urbano, depara-se com as Idades Média e Moderna; com o românico e o gótico, o manuelino e o barroco; com edifícios político-administrativos, militares e religiosos - da Coroa, da nobreza e do clero católico, dos concelhos e da burguesia. Relativamente ao património cultural móvel, classificado e salvaguardado em espaços de museologia tradicional, resumiu-se, no essencial, a vestígios arqueológicos comprovativos das «nobres origens da Nação», à arte erudita ilustrativa da "grandeza da Pátria», a vestígios etnológicos (nacionais ou regionais / locais) e etnográficos (coloniais), à história das ciências da natureza. As principais exclusões tiveram a ver com os «não europeus» e com «outras religiões» - magrebinos e negros, muçulmanos ou judeus, escravos, "cristãos novos» e «marranos»-, com a cultura material (mesmo das épocas moderna e contemporânea), com o novo património cultural e a nova museologia.

Pretendendo influenciar e regenerar, desativar e mobilizar, exclusiva e permanentemente, tanto as elites como os grupos intermédios e parte substancial das «classes populares», o salazarismo organizou, com regularidade, elaboradas e coerentes comemorações histórico-patrióticas. Promoveu, ainda, a convergência sistemática entre a sua narrativa sobre «o passado» e a propaganda - política e sindical, religiosa e associativa -, a comunicação social e a publicidade, a produção artística em geral e a estatuária em particular, a toponímia e a numismática. Será, assim, operatório afirmar que a estratégia de configuração da memória histórica (sob a forma do historicismo neo-metódico) foi um dos vetores nucleares da mundividência do Estado Novo. 
De entre as múltiplas iniciativas de «encenação do passado», evoco, a partir de 1934, as comemorações anuais do «Dia da Raça» (10 de junho), ou seja, das supostas características identitárias do «Povo Português» e da respetiva capacidade para se expandir pelo Mundo (como descobridores e colonizadores/civilizadores, enquanto agentes económicos ou emigrantes). Desde o ano de 1940, em Coimbra, o Portugal dos Pequenitos, espaço «lúdico-pedagógico» de inculcação de vertentes da ideologia - nacionalismo e historicismo, ruralismo e colonialismo - do Estado Novo junto «das crianças e do povo». Em 1947, as Comemorações do VIII Centenário da Tomada de Lisboa aos Mouros (1147), momento, tanto de reafirmação da matriz «Católica e Ocidental da Nação Portuguesa», como de exclusão dos muçulmanos e judeus (inimigos do catolicismo e Orientais). No ano de 1960, as Comemorações Henriquinas, integradas no esforço de relegitimação do colonialismo português no contexto do pós-Segunda Guerra Mundial, nomeadamente recorrendo à perspetiva «luso-tropicalista».

O principal destaque é, no entanto, devido às massivas Comemorações do Duplo Centenário da Fundação da Nacionalidade (1140) e da Restauração (1640), ocorridas, em 1940 - de junho a dezembro -, sobretudo em Lisboa mas, também, no resto «da Metrópole, nas Ilhas Adjacentes e nas Colónias». Significativamente, o programa das comemorações foi iniciado e concluído com dois Te Deum na Sé Catedral de Lisboa (2 de junho e 1 de dezembro). Seguiram-se, entre outras, as cerimónias alusivas à «Fundação de Portugal» (a 4 de junho, na «cidade berço» de Guimarães); a Exposição do Mundo Português (Lisboa, 23 de junho a 2 de dezembro); o Congresso do Mundo Português ${ }^{(6)}$ e o Congresso Internacional da Mocidade (Lisboa); o desfile alusivo à «Restauração da Independência» (a 1 de dezembro, em Lisboa), com «os estandartes dos Municípios, das Corporações, da Legião Portuguesa e da Mocidade Portuguesa».

(6) Congresso de Pré e Proto-História de Portugal (Universidade do Porto), Congresso de História Medieval de Portugal (Universidade de Coimbra), Congresso de História dos Descobrimentos e Colonização Portugueses (Universidade de Lisboa), Congresso de História da Monarquia Dualista e da Restauração (Universidade de Lisboa), Congresso de História Moderna de Portugal (Universidade de Lisboa), Congresso de História Contemporânea de Portugal (Universidade de Lisboa), Congresso Luso-Brasileiro de História (Universidade de Lisboa), Congresso de História da Atividade Científica Portuguesa (Universidade de Coimbra), Congresso Colonial (Universidade de Lisboa) e Congresso Nacional de Ciências da População (Universidade do Porto), cujas atas foram publicadas na íntegra (Cf. Congresso do Mundo Português, 19 vols., Porto, Imprensa Portuguesa, 1940). 


\section{Estado Novo e antissemitismo ${ }^{(7)}$}

Tanto ao longo da ditadura como após o Golpe Militar e a Revolução do 25 de Abril de 1974, o discurso político e muita da produção historiografia têm coincidido no balanço segundo o qual o salazarismo evitou promover conceções darwinistas sociais e não adotou posturas antissemitas ativas. Antes da e durante a Segunda Guerra Mundial, quaisquer afirmações ou práticas eventualmente classificáveis como antissemitas, ocorridas em Portugal, decorreriam, apenas, de resquícios de antijudaísmo atávico, instintivamente mantido, nas classes populares rurais, devido à luta travada, contra mouros e judeus, na Idade Média e na Idade Moderna; as tensões nacionalistas face a cidadãos estrangeiros; ao esforço para não provocar reações agressivas por parte de grandes potências como a Alemanha durante o Terceiro Reich.

Resolvida a «ameaça judaica» nos séculos XVI a XVIII, tendo herdado uma pequena comunidade israelita - integrada na «Nação Lusa» e sobretudo concentrada em Lisboa, posicionada nas «classes altas» e com ligações ao Reino Unido -, o Estado Novo ter-se-ia limitado a evitar o regresso «do problema judaico», o qual seria necessariamente gerado pela entrada no país de quantitativos significativos de indivíduos de origem judaica. Daí as vantagens de impedir, a título preventivo, por um lado, a emergência de ideologias antissemitas radicais; por outro, a reconversão dos «marranos» ao judaísmo e o aumento do número

(7) Cf., nomeadamente, Maria das Graças Ataíde de Almeida, A construção da verdade autoritária (1937-1945), São Paulo, USP/Humanistas, 2001; David Bankier (ed.), Probing the depths of german antisemitism, Jerusalém, Yad Vashem, 2001; David Bankier e Israel Gutman (ed.), Nazi Europe and the final solution, Jerusalém, Yad Vashem, 2009; David Bankier e Dan Michan (ed.), Holocaust and justice, Jerusalém, Yad Vashem, 2010; Richard Breitman, Os segredos do Reich que os Aliados sabiam (trad. do inglês), Lisboa, Âncora Editora, 2001; Christopher Robert Browning, The origins of the Final Solution, Jerusalém, Yad Vashem, 2004; Maria Luiza Tucci Carneiro, O anti-semitismo na Era Vargas, São Paulo, Perspectiva, 2001, $3^{\mathrm{a}}$ ed.; Susana Chalante, «O discurso do Estado salazarista perante o 'indesejável'..., cit., p. 6; Manuela Franco, «Judeus em Portugal», in Maria Filomena Mónica e António Barreto (coord.), Dicionário de História de Portugal. Suplemento, Porto, Livraria Figueirinhas, 1999, vol. 8, p. 314-324; Manuela Franco, «Uma influência portuguesa no Levante? A diplomacia ao serviço da propaganda do prestígio da República», Política Internacional, Outono/Inverno 2002, p. 187-206; Saul Friedländer, The years of persecution. Nazi Germany and the jews (19331939), Londres, Phoenix, 2007; Saul Friedländer, The years of extermination. Nazi Germany and the jews (1939-1945), Nova Iorque, Harper Perennial, 2007; Israel Gutman, Holocausto 
de judeus estrangeiros (imigrantes, refugiados ou exilados) a viver «na Metrópole, nas Ilhas Adjacentes ou nas Colónias».

Confirmando a reconstituição e interpretação em causa estariam o comportamento moderado da Igreja e da «ação católica» nacionais perante o aumento da influência, à escala europeia e mundial, de conceções darwinistas sociais e antissemitas; a quase ausência de violência ideológica ou social contra judeus, em Portugal, nas décadas de 1930 e 1940; as boas relações políticas e pessoais existentes entre Moisés Bensabat Amzalak (Presidente da Comunidade Israelita de Lisboa, professor universitário de economia e dirigente da Associação Comercial de Lisboa, administrador do jornal O Século e Procurador à Câmara Corporativa, etc.) e António de Oliveira Salazar - ou entre a comunidade judaica lusa e o Estado Novo -; a recusa do Governo de Lisboa em ceder às exigências de Berlim no que concerne à introdução de legislação que discriminasse cidadãos de origem judaica e a permanência do nosso país na «área de influência» britânica; a atitude relativamente benigna mantida, face aos refugiados de origem judaica, durante a Segunda Guerra Mundial.

Nas últimas duas década foram, entretanto, publicados diversos estudos que tendem a questionar em parte os consensos estabelecidos. Perante a realidade portuguesa e por comparação com o ocorrido em outros países até 1939 (na Europa Ocidental e no Continente Americano

y memoria (trad. do hebraico), Jerusalém, Yad Vashem, 2003; Mike Hawkins, Social darwinism in european and american thought (1860-1945), Cambridge, CUP, 1998, $2^{\mathrm{a}}$ ed.; Helena Pinto Janeiro, Salazar e Pétain. Relações luso-francesas durante a II Guerra Mundial (1940-44), Lisboa, Edições Cosmos, 1998; Manuel Loff, As duas ditaduras ibéricas na nova ordem eurofascista..., cit., p. 6; António Louçã e Isabel Paccaud, O segredo da Rua d'O Século, Lisboa, Fim de Século, 2007; Lina Madeira, Alberto da Veiga Simões. Esboço de uma biografia política, Coimbra, 2000 (policopiado); Lina Madeira, O mecanismo de (des)promoções do MNE. O caso paradigmático de Aristides de Sousa Mendes, 2 vols., Coimbra, 2013 (policop.); Jorge Martins, «O moderno anti-semitismo em Portugal..., cit., p. 6; Jorge Martins, Portugal e os judeus, 3 vols., Lisboa, Editorial Vega, 2006; Jorge Martins, A República e os judeus, Lisboa, Nova Vega, 2010; Elvira de Azevedo Mea e Inácio Steinhardt, Ben-Rosh. Biografia do Capitão Barros Basto..., cit., p. 6; João Medina e Joel Barromi, «O projecto de colonização judaica em Angola», Clio, 6 (1987/1988), p. 79-105; João Medina, «António Sardinha, anti-semita», A Cidade, 2, jul.dez. 1988, p. 45-122; João Medina, «O caso Dreyfus em Portugal», Revista da Faculdade de Letras [UL], V série, 16/17 (1994), p. 115-231; Avraham Milgram (ed.), Entre la aceptatión y el rechazo. América Latina y los refugiados judíos del nazismo, Jerusalém, Yad Vashem, 2003; Avraham Milgram, Portugal, Salazar e os judeus..., cit., p. 6; Lúcia Liba Mucznik e outros (coord.), Dicionário do judaísmo português..., cit., p. 6; Patrick von zur Mühlen, Caminho de fuga Espanha-Portugal. A emigração alemã e o êxodo para fora da Europa de 1933 a 1945, Coimbra, IUC, 2012; João Paulo Avelãs Nunes, 
de modo parcelar, na Europa de Leste de forma extremada), confirma-se a avaliação segundo a qual o salazarismo não dinamizou nem tolerou discursos, legislação ou práticas - político-administrativas e sociais antissemitas de cariz sistémico e explícito. Propõe-se, ao mesmo tempo, ser operatório afirmar que a ditadura lusa cultivou e autorizou leituras darwinistas sociais, mundividências antissemitas (algumas sob a capa de «meras rememorações antijudaicas»), estratégias político-administrativas e interações sociais encapotada ou controladamente antissemitas.

Segundo os partidários desta hipótese, entre os quais me encontro, não só a investigação historiográfica recentemente concretizada permite sustentar a natureza objetivante da abordagem citada, como se identificaram as potencialidades, por um lado, de rastrear e de analisar novas séries de vestígios relevantes; por outro, de revisitar núcleos documentais já considerados para estudar outras problemáticas. Elencam-se, a este propósito, publicações periódicas generalistas e de organizações políticas, da Igreja e da «ação católica», de associações empresariais e sindicais, etc; manuais de História dos vários níveis de ensino e obras de divulgação cultural ou científica; monografias, coletâneas de discursos e de outras intervenções públicas de personalidades significativas, atas de eventos políticos e religiosos, económicos e culturais (nacionais ou internacionais) $)^{(8)}$.

A história económica e social na FLUC..., cit., p. 10; João Paulo Avelãs Nunes, O Estado Novo e o volfrâmio (1933-1947), Coimbra, IUC, 2010; João Paulo Avelãs Nunes, «Neo-darwinism and politico-ideological concepts in Portugal during the first half of the 20th century», in Ana Leonor Pereira e outros (ed.), Darwin, evolution, evolutionisms, Coimbra, IUC, 2011, p. 151-155; João Paulo Avelãs Nunes, «Darwinismo social e antisemitismo..., cit., p. 6; Livia Parnes, Présences juïzes dans le Portugal contemporain..., cit., p. 6; Ana Leonor Pereira, Darwin em Portugal..., cit., p. 6; Michael Phayer, The Catholic Church and the Holocauste (1930-1965), Bloomington, Indiana University Press, 2000; Irene Flunser Pimentel, Judeus em Portugal durante a II Guerra Mundial..., cit., p. 6; Irene Flunser Pimentel e Cláudia Ninhos, Salazar, Portugal e o Holocausto..., cit., p. 6; Gabriel de Jesus Pita, A Igreja Católica perante o nacionalismo português do Estado Novo..., cit., p. 7; Isabelle Rohr, The spanish right and the jews (1898-1945), Londres, Sussex Academic Press, 2008; Bernd Rother, Franco y el Holocausto (trad. do inglês), Madrid, Marcial Pons, 2005; Ansgar Schaefer, Portugal e os refugiados judeus provenientes do território alemão..., cit., p. 6; David Vital, A people apart. The jews in Europe (1789-1939), Oxford, OUP, 2009, 2a ed.; Bernard Wasserstein, On the eve. The jews of Europe before the Second World War, Londres, Profile Books, 2012; Michel Winock, Nationalisme, antisémitisme et fascisme en France, Paris, Éditions du Seuil, 1982.

(8) Cf., por exemplo, Manuel Gonçalves Cerejeira, Obras pastorais, 7 vols., Lisboa, União Gráfica, 1936-1970; Dez anos de política externa (1936-1948). A nação portuguesa e a Segunda Guerra Mundial, 15 vols., Lisboa, MNE/IN, 1961-1993; Lina Madeira, Correspondência de um diplomata no III Reich, Coimbra, Mar da Palavra, 2005; Manuel Homem de Mello, Eu 
Para caracterizar e explicar a correlação entre nacionalismo, darwinismo social e antissemitismo no Estado Novo, começo por lembrar a ocorrência, em momentos ao longo do século XIXe no primeiro quartel do século XX, de situações de violência contra «marranos», apontados como corresponsáveis pelas Invasões Francesas ${ }^{(9)}$, e de tentativas de afastar agentes económicos concorrentes denunciando a respetiva origem judaica (sinónimo de imoralidade). A reprodução de preconceitos antissemitas - a propósito de realidades nacionais ou estrangeiras, passadas ou presentes - em textos literários e jornalísticos ${ }^{(10)}$. O amplo envolvimento português nas polémicas a propósito do Affaire Dreyfus (ano 1894 e seguintes) e a intensa condenação da suposta ligação entre «os judeus», a Maçonaria e o republicanismo.

Indico, ainda, a publicação e divulgação, por setores monárquicos autoritários, da obra Protocolos dos Sábios de Sião ${ }^{(11)}$ e o ressurgimento de uma produção historiográfica com elementos de antissemitismo (ver,

vi morrer o III Reich, Lisboa, Editorial Vega, 1982; António da Silva Pena Peralta [Paulo de Tarso], Crimes da franco-maçonaria judaica, Guarda, Empresa Veritas, 1928; Mário Saa, A invasão dos judeus, Lisboa, Libânio da Silva, 1925; António de Oliveira Salazar, Discursos e notas políticas, 6 vols., Coimbra, Coimbra Editora, 1945-1967; António Sardinha, O valor da raça, Lisboa, Almeida, Miranda \& Sousa, 1915.

(9) «A insurreição popular não só revestiu inequívocas motivações sociais como permitiu agitar ancestrais representações sócio-religiosas. $\mathrm{O}$ anti-semitismo ressurgiu com surpreendente força em enclaves geográficos de tradição cristã-nova como Bragança, Moncorvo, Guarda, Viseu, Covilhã, Fundão e Vila Nova de Foz Coa. Nesta vila, a população manteve-se levantada contra os Franceses e 'os judeus que os protegiam' durante 15 dias. A imagem do satânico opressor, aplicada ao ocupante francês, desdobrou-se, internamente, na do jacobino e do judeu, ambos potenciais subversores da ordem pública e religiosa. Naturalmente que o clero não foi alheio a este processo de clivagem social e cultural». (Cf. Ana Cristina Araújo, «Política e diplomacia na Era das Revoluções», in Luís Reis Torgal e João Lourenço Roque (coord.), O Liberalismo (1807-1890), José Mattoso (dir.), História de Portugal, Lisboa, Círculo de Leitores, 1993, vol. V, p. 35/36)

(10) «A antiga legenda do israelita, magro, esguio, adunco, caminhando cosido com a parede, e coando por entre pálpebras um olhar turvo e desconfiado, pertence ao passado. $\mathrm{O}$ judeu hoje é um gordo. Traz a cabeça alta, tem a pança ostentosa e enche a rua. É necessário vê-los em Londres, em Berlim, ou em Viena: nas menores coisas, entrando em um café ou ocupando uma cadeira num teatro, têm um ar arrogante e ricaço, que escandaliza. A sua pompa espectaculosa de Salomões parvenus ofende o nosso gosto contemporâneo, que é sóbrio. Falam sempre alto, como em país vencido, e num restaurante de Londres ou de Berlim nada há mais intolerável que a gralhada semítica. Cobrem-se de jóias, todos os arreios das carruagens são de ouro, e amam o luxo grosso. Tudo isto irrita». (Cf. Elza Miné e Neuma Cavalcante (ed.), Edição crítica das obras de Eça de Queirós. Textos de imprensa, Lisboa, IN-CM, 2002, vol. IV, p. 110)

(11) Cf. Francisco Pereira de Sequeira e José de Lemos Peixoto, Os planos da autocracia judaica: Protocolos dos Sábios de Sião, Porto, Livraria Portugueza, 1923. 
por exemplo, História dos christãos novos portugueses $\left.{ }^{(12)}\right)$. O argumentário antissemita presente nos debates acerca de um projeto de instalação de colonos de origem judaica em Angola e sobre a concessão da nacionalidade portuguesa a judeus de origem lusa residentes no Mediterrâneo Oriental. O peso do antissemitismo nas ideologias e na atividade do Integralismo Lusitano e do Movimento Nacional-Sindicalista.

Relativamente ao salazarismo propriamente dito, deparamos com vetores de antissemitismo antes e após o eclodir da Segunda Guerra Mundial e do Holocausto. Acerca dos anos trinta, saliento a defesa sistemática da legitimidade, da necessidade e das vantagens da «guerra contra os judeus» - expulsão e conversão forçada, condenação e perseguição de vivências religiosas e de outras práticas culturais, diferenciação entre «cristãos velhos» e «cristãos novos» - concretizada, nos séculos XVI a XVIII, pela «Nação Lusa» (Estado, Igreja Católica e «sociedade civil»). A recusa em promover o conhecimento e a divulgação da cultura judaica em geral e do ladino em particular; em estabelecer contatos e em rentabilizar a subsequente cooperação com as comunidades de sefarditas existentes noutros Estados, descendentes dos judeus expulsos ou fugidos do nosso país e de Espanha na Idade Moderna.

Considero, também, a reação do Governo e do aparelho de Estado, da Igreja e da «ação católica» contra o «Resgate dos Marranos», iniciativa liderada por Artur Barros Basto, a partir da Sinagoga do Porto, com os objetivos de identificar e de valorizar os «cripo-judeus» portugueses, de viabilizar o restabelecimento das ligações entre os mesmos e a diáspora judaica. A presença de tópicos de antissemitismo em várias das frentes da luta pela consolidação da hegemonia ideológica da ditadura, nomeadamente perante as dúvidas acerca do regime político a adotar ${ }^{(13)}$, face à «questão social» e sobre a escolha entre «arte nacional»e «arte cosmopolita».

(12) Cf. João Lúcio de Azevedo, História dos christãos novos portugueses, Lisboa, Livraria Clássica Editora, 1921.

(13) Segundo a Redação do católico O Trabalhador, estaria «provado por documentos encontrados na Hungria e em outros países da Europa Central que foi o dinheiro judaico que fomentou diversos levantamentos comunistas que ensanguentaram esses países após a Guerra: Trotsky, Zinoviev, Kamenef, Litvinof, Radek, Karl Marx, Liebknecht, Rosenthal, Rosa Luxemburg, Bela-Kuhn, Borodin... são judeus. Rosenberg, o embaixador da Rússia que dirigiu a revolução marxista na Espanha, é semita. Do que os algozes de Cristo são capazes vê-se pela seguinte carta da Sinagoga, escrita no século XV: 'Fingi aceitar o cristianismo para que maior dano possais causar aos cristãos. Dedicar-vos-eis às letras, e com a vossa teologia subvertereis a fé dos cristãos; com vossa jurisprudência os despojareis; com 
Evoco a responsabilização «dos judeus» - conspirativos e ambiciosos, plutocratas mas financiadores de revolucionários, anticristãos e inimigos das Nações - pela violência, de Estado e social, que contra os mesmos era perpetrada na Alemanha e em outros países europeus, apesar das críticas aos «excessos praticados» e, sobretudo, ao desrespeito pelos indivíduos que se tinham convertido ao catolicismo ${ }^{(14)}$. Lembro, finalmente, a partir de meados da década de 1930, o esforço para impedir a entrada em Portugal de refugiados alemães de origem judaica, impedidos de regressar ao seu país pelo Terceiro Reich; acusados de serem portadores de conceções e de comportamentos subversivos e imorais, de serem inimigos do catolicismo e dos "países com Governos de ordem», de serem aliados da «Rússia comunista» e da «América plutocrática». A orientação em causa foi imposta por António de Oliveira Salazar enquanto Chefe do Estado Novo e defendida, quer pela PVDE, quer por muitos quadros superiores do Ministério dos Negócios Estrangeiros.

Durante o conflito de 1939 a 1945, confrontada com a heterodoxa iniciativa de Aristides de Sousa Mendes, a ditadura lusa exigiu que o custear das despesas com os refugiados judeus fosse assegurado pela Comunidade Israelita de Lisboa ou por organizações estrangeiras; estabeleceu o propósito de que todos os «refugiados israelitas» abandonassem o país, abdicando,

medicina matareis impunemente; abusareis dos benefícios eclesiásticos e dos sacramentos e à Igreja pertencereis. Entrando nos mosteiros, perturbareis a paz e a concórdia. Finalmente, ocupareis discretamente os lugares seculares e dedicar-vos-eis às artes para devorar os bens dos cristãos sem trabalho'. O trabalho judaico vai tomando, dia e noite, maior importância devido à autêntica invasão dos emigrados alemães. Não se pode combater o comunismo sem combater os seus aliados da franco-maçonaria e do judaísmo internacional». (Cf. Redacção, «Os judeus e o comunismo», O Trabalhador, Ano III, 69, 1 mar. 1937, p. 4)

(14) De acordo com a Direção da Associação Industrial Portuguesa, «os judeus da Alemanha tinham invadido as universidades, os tribunais, a imprensa, o teatro, o cinematógrafo, a medicina, as letras e as artes, a banca e a Bolsa, o grande comércio. Isto prova a sua inteligência e as suas capacidades. Eis algumas cifras: dos 3450 advogados de Berlim, 1925 eram judeus e 1525 arianos [...]. Em 1914, 30\% das cátedras universitárias eram já ocupadas por judeus; em 1932, na Faculdade de Medicina de Berlim, a percentagem era de $45 \%$ [...]. Dos 29 empresários de teatros de Berlim, 23 eram judeus, ou seja $80 \% ; 75 \%$ das peças de teatro representadas nestes últimos anos foram escritas por judeus. Os bancos judaicos são os mais importantes da Alemanha [...]. Enfim, os grandes chefes revolucionários, desde Karl Marx [...], foram ou são judeus. Em resumo, era um facto que a influência judaica predominava cada vez mais e por toda a Alemanha, ao ponto de os cristãos se sentirem pouco a pouco eliminados. Uma reacção era necessária. Foi espontânea. Foi brutal. Foi imprudente. Produziu-se então e ainda hoje se dão em toda a Alemanha actos de anti-semitismo repreensíveis». (Cf. Redacção, «Os judeus na Alemanha», Indústria Portuguesa, $12^{\circ}$ ano, 132, (Fev. 1939), p. 14) 
ao mesmo tempo, de procurar fixar indivíduos de origem portuguesa e/ ou com competências profissionais pouco frequentes. Respondeu, ainda, negativamente à maioria das perguntas de Berlim sobre se Portugal estava interessado em acolher judeus que afirmavam ter cidadania e/ou origens portuguesas, mesmo quando reivindicou o direito de gerir os respetivos bens em territórios ocupados pela «Grande Alemanha».

Ao longo da década de 1940 (mesmo depois dos Julgamentos de Nuremberga), o Governo de Lisboa evitou condenar o Terceiro Reich e outros Estados corresponsáveis pelo Holocausto, mau grado ter acompanhado a escalada de antissemitismo desde 1933 e ter tido conhecimento, pelo menos desde o Outono de 1941, do genocídio desencadeado desde o início da invasão da URSS (a 22 de junho de 1941). Podendo, embora, ser explicável a partir de múltiplos condicionalismos - um dos quais dificilmente será a defesa do direito do povo palestiniano à autodeterminação e à independência -, não deixa de ser significativo que Portugal só tenha aceitado estabelecer relações diplomáticas com Israel em 1977, já depois do Golpe Militar e da Revolução de 25 de Abril de 1974, bem como da consolidação de um regime democrático.

\section{Antijudaísmo e antissemitismo na memória histórica do Estado Novo}

Coerentemente com o propósito de naturalização e de consensualização de uma ideologia totalitária, com a estratégia de consolidação e de reprodução do regime tendo em conta alguns constrangimentos internos e externos, o salazarismo escolheu, pois, o louvor do antijudaísmo português dos séculos XVI a XVIII como a concretização mais operatória da sua componente de antissemitismo. Partindo de nacionalismos tradicionalistas, conservadores e modernizadores, da democracia-cristã neotomista e de um darwinismo social difuso, a ditadura lusa preferiu a abordagem historicista, tanto pelos respetivos prestígio e eficácia legitimadora, como pelo seu caráter relativamente distanciado e preventivo, moderado e controlado ${ }^{(15)}$.

(15) Cf., entre outros, Manuel Loff, As duas ditaduras ibéricas na nova ordem eurofascista..., cit., p. 6 e 14; João Paulo Avelãs Nunes, O CADC de Coimbra, a democracia cristã e os inícios do Estado Novo..., cit., p. 6; João Paulo Avelãs Nunes, A história económica e social na FLUC..., cit., p. 10 e 15; João Paulo Avelãs Nunes, «As organizações de juventude e a memória histórica do Estado Novo..., cit., p. 6 e 12; João Paulo Avelãs Nunes, O Estado Novo e o volfrâmio..., cit., p. 15; João Paulo Avelãs Nunes, «O Estado, a historiografia e outras 
Na perspetiva do dirigente e do apoiante-tipo do Estado Novo, «os judeus» eram uma ameaça permanente enquanto praticantes de uma religião e, em geral, de uma cultura malignas (ou, pelo menos, exóticas e inferiores); enquanto Nação sem território nem Estado; enquanto «raça oriental» (não europeia nem ocidental). Ao contrário de outros países europeus e americanos, Portugal teria resolvido o seu "problema judaico» durante a idade moderna. Apesar dos erros cometidos desde 1807 ou 1820 - fim da identificação, da segregação e do controlo (preventivo e punitivo) dos judeus -, mesmo na época contemporânea o «perigo judaico» estaria contido porque se assistiu ao manter da caraterização do judaísmo como realidade exótica e da condenação do mesmo, à aparente ou efetiva integração dos membros da pequena comunidade judaica na «Nação Lusa», à segmentação e neutralização dos dispersos e aculturados grupos de «marranos». Bastaria, assim, manter o status quo vigente, evitar a entrada ou a (re)conversão de mais judeus e impedir o eclodir de novas polémicas públicas sobre «os israelitas» (despoletadas por fenómenos nacionais ou internacionais).

Prolongando níveis de explicitude e de radicalismo típicos do último quartel do século XIX e do primeiro quartel do século XX, alguns intelectuais continuaram, no entanto, nas décadas de 1930 e de 1940, em âmbitos mais ou menos restritos, a defender posições abertamente antissemitas. «Os judeus» seriam uma «raça» e uma Nação orientais e não assimiláveis, cultivariam um atavismo religioso e o ódio ao catolicismo, utilizariam, sistematicamente, todas as modalidades de desagregação da «ordem» social e política. Recorria-se, também, com frequência, a exemplos e a argumentos retirados «do passado», afirmando-se que «os judeus» sempre odiaram «os cristãos» e tentaram dominar o Mundo, utilizando, para o efeito, múltiplos «estratagemas ínvios». Adicionavamse, pois, os mitemas do antijudaísmo medieval e moderno às narrativas do antissemitismo contemporâneo.

A título meramente ilustrativo, assinalo e procuro analisar alguns exemplos de produção intelectual que correspondem aos dois perfis que acabei de propor. Coloco a hipótese de se tratar de posturas bem mais numerosas e relevantes entre nós do queé habitual considerar, justificando-

ciências/tecnologias sociais..., cit., p. 10 e 12; Irene Flunser Pimentel e Cláudia Ninhos, Salazar, Portugal e o Holocausto..., cit., p. 6 e 15; Luís Reis Torgal e outros, História da história em Portugal..., cit., p. 10 e 12. 
se um estudo sistemático desta problemática. Chamo a atenção para a explicitude e para a naturalidade, para o rigor terminológico e para a abundância de estratégias argumentativas antissemitas presentes incluindo a remissão para obras dos principais historiadores portugueses da segunda metade do século XIX e do primeiro quartel do século XX -, durante a Ditadura Militar e durante a primeira década do Estado Novo, nos vetores de construção de memória histórica citados.

Começo por salientar a História de Portugal de Fernando Falcão Machado, editada em 1928 enquanto resumo «das lições magistrais de História de Portugal ( $1^{\circ}$ Ano) pelo Exmo. Professor Senhor Doutor Manuel Gonçalves Cerejeira, no ano letivo de 1927/1928 na Faculdade de Letras da Universidade de Coimbra» ${ }^{(16)}$. Só pareceu necessário evocar «os judeus» nas vésperas da respetiva expulsão e conversão forçada, pouco antes da implantação do Tribunal do Santo Ofício. De acordo com o autor da «sebenta» e com o futuro Cardeal Patriarca de Lisboa,

no século XVI há uma purificação da Raça pela expulsão dos Judeus, bem como a dos Mouros.

Havia a opinião de que a unidade religiosa havia de ser a base da unidade nacional. Os judeus converteram-se ao cristianismo, mas foi uma falsa conversão. Praticam a ocultas o rito da sua religião. O problema agrava-se do século XVI em diante. Os Judeus eram indignos. Ameaçavam corromper a alma nacional. Usavam de simulação. Era a traição das virtudes do apanágio da nossa civilização: coragem, lealdade, sinceridade. Ocupavam postos superiores no Estado, mediante o fingimento de professarem uma religião que, no fundo, detestavam. Feita a purificação no interior, a cruzada projecta-se além fronteiras. (p. 8)

Observemos, em segundo lugar, a obra Portugal na história da Civilização, publicada em 1928 por António Serras Pereira, professor do Ensino Liceal ${ }^{(17)}$. Pretendeu-se, essencialmente, reafirmar a natureza negativa «dos judeus» e lembrar o eterno projeto daquele «povo oriental»

(16) Cf. Fernando Falcão Machado e Júlio Catarino Nunes, História de Portugal. Súmula das lições magistrais de História de Portugal $\left(1^{\circ}\right.$ Ano) pelo Exmo. Professor Senhor Doutor Manuel Gonçalves Cerejeira, no ano lectivo de 1927/1928 na Faculdade de Letras da Universidade de Coimbra, Coimbra, Tipografia da Gráfica Conimbricense, 1928.

(17) Cf. António Serras Pereira, Portugal na história da civilização, Lisboa, Edição de José Fernandes Júnior, 1928. 
de destruição da "Civilização Cristã e Ocidental", de concretização de uma estratégia de domínio a nível mundial. Quis-se caraterizar a situação política portuguesa, nos reinados de D. Fernando I a D. João III, à luz de um pretenso conflito entre a «Nação Portuguesa» e a «Raça Judaica»; demonstrar a centralidade de Portugal como "defensor do Ocidente" na luta contra a «Internacional judaica».

Referindo-se aos judeus, A. Serras Pereira afirmava que o

seu anti-nacionalismo (em relação às outras nacionalidades), filho de um nacionalismo ferrenho, obrigava-os a organizar-se em uma vasta Internacional [...]. Destituídos, todavia, das vulgares garantias, e tendo de arcar com os riscos da vida capitalista e comercial, eram levados pela dura necessidade a procurar no açambarcamento, no monopólio e na usura, a única garantia preventiva, susceptível de ser por eles adquirida. Mas, o ódio que desta maneira fomentavam nas populações, deles economicamente dependentes, agrava-lhes o precário da situação.

Os judeus defendiam-se dando as mãos aos inimigos externos e internos, assim como a todos os elementos dissolventes da sociedade [...]. Nisto tivera o perigo judaico a sua máxima gravidade. Verdadeiro estado dentro de outro estado, e portador duma civilização antagónica, irredutível e inassimilável, o judeu representava sempre um perigo excepcional. Daí o seu carácter congenitamente revolucionário e subversivo. Por outro lado a função preponderante da sua Internacional, especulando com os destinos e interdependência dos povos, era de molde a alimentar-lhes a esperança de domínio exclusivo do mundo, uma vez posta em prática a projectada e para eles indispensável ruina geral. (p. 107/108)

Utilizando uma linguagem marcada por um certo «radicalismo anti-plutocrático» e por um elevado grau de anacronismo, o autor de Portugal na história da Civilização, invocando o reinado de D. Fernando I, defendeu que numa

altura em que o capitalismo internacional com a finança judaica à frente, reinava em absoluto, por intervenção da praça de Lisboa sobre Portugal, minando por completo toda a possibilidade duma política de fomento eficaz, urgia consolidar o Estado dentro duma base territorial mais vasta para ficar à altura de desempenhar a sua função protectora. Só dentro dessa nova situação surgiria um poder real suficientemente forte para efectivar essa política que ressalvasse as vilas e a conservadora 
nobreza rural dos gravames da parasitária, dissolvente e revolucionária nobreza cavalheiresca dos filhos segundos, dos sem terra, não associados, portanto, à produção interna. (p. 52)

Depois de, nos reinados de D. João I a D. Afonso V, supostamente «os judeus» terem voltado a dominar no nosso país, verificando

que em Portugal tinham entrado clandestinamente maior número de judeus que os do pactuado, D. João II providenciou contra essa gente suspeita, reduzindo-os à escravidão. Terminado o prazo, os judeus admitidos são embarcados e entregues à discrição dos comandantes dos navios, destituídos de todas as garantias, como era natural. Assim, mais uma vez, pudera D. João II conciliar os interesses do país com os mais altos sentimentos de humanidade. Tirando as crianças a essa raça proscrita, D. João II salvaguardava-as da tragédia que inevitavelmente lhes vitimaria os pais. Por outro lado, povoava com eles São Tomé [...], entregando-os aos cuidados dos colonos aí estabelecidos. (p. 139/140)

Finalmente, face à proclamada reconstituição da hegemonia judaica no reinado de D. Manuel I, D. João III procurou salvar o país exigindo a criação do Tribunal do Santo Ofício:

Tendo bem presente o carácter teocrático, exclusivista e autocrático do Estado judaico, negação de toda a possibilidade de independência económica, civil e moral e lembrando-nos de quanto desse Estado dependeria intimamente a vida económica e o meneio da política internacional portuguesa, avaliar-se-á a gravidade desse momento excepcional. Tolerar o judeu era tolerar, além da teocracia, o seu feroz predomínio. Aniquilá-lo seria, por outro lado, aniquilar a nossa mais importante força económica. Como conciliar semelhante paradoxo? Ora foi precisamente para o conjurar, salvando-nos dessa situação desesperada, que agora nos vai aparecer a Inquisição. (p. 232/233)

É verdade que nos momentos críticos de terrorismo declarado, a Inquisição não poderia usar de muitas delongas em procurar, pelos meios de correcção, poupar o conspirador à jurisdição penal da época. Todavia o número de condenados à pena capital ficou sendo uma fracção insignificantíssima, e tanto mais e nos lembrarmos do que sucederia, se em certos momentos de terror faltasse a moderadora acção inquisitorial. Então se veria quantas execuções os governos 
seriam forçados a fazer para darem uma satisfação às populações aterrorizadas e prestes, em caso contrário, a precipitarem-se em convulsões das mais sangrentas da história de todos os tempos. Isto a não triunfar o calamitoso despotismo político, económico e religioso do judeu, o qual, uma vez realizadas as suas esperanças messiânicas, reduziria a Cristandade a uma implacável escravidão. A Inquisição, contendo o judeu debaixo de uma rigorosa vigilância, debelou, logo de princípio, por um lado, a sua tremenda revolução social, por outro, a possibilidade do país ser por ele abandonado subitamente - o que também representaria um grau de ameaça para a vida económica da nação. (p. 235/236)

Consideremos, num terceiro momento, o manual escolar Elementos de História de Portugal, «elaborado para uso do Ensino Secundário, absolutamente de acordo com o respetivo Programa», da autoria de Alfredo Pimenta - figura marcante da intelectualidade lusa na primeira metade do século XX - e com primeira edição em $1934^{(18)}$. As únicas referências «aos judeus» são feitas a propósito dos reinados de D. Manuel e de D. João III, ou seja, no contexto de introdução da Inquisição:

Na Península hispânica, lutava-se desde há muito tempo contra o predomínio dos judeus na vida económica do Estado e dos particulares, e contra o perigo que eles e outros hereges constituíam para a pureza da Fé católica. (p. 238)

Os abusos a que os tribunais da Inquisição por ventura deram aso; as violências praticadas; as injustiças e precipitações nas sentenças; as paixões exacerbadas - tudo quanto é possível encontrar nesses tribunais e é inerente a qualquer tribunal, júri de concursos, tribunal judicial, de arbitragem, etc. - ficam muito aquém dos altíssimos serviços que eles prestaram à civilização portuguesa, à pureza do nosso sangue e da nossa fé, e à ordem pública. Sem eles, o perigo judaico ter-nos-ia arruinado, porque a população portuguesa ver-se-ia impelida para grandes e tumultuosas revoltas contra os judeus. (p. 252)

Também no Compêndio de História Universal, de António Gonçalves Mattoso - eventualmente o mais importante autor de manuais de História

(18) Cf. Alfredo Pimenta, Elementos de história de Portugal, Lisboa, Empresa Nacional de Publicidade, 1934. 
do salazarismo -, livro obrigatório para os $4^{\circ}$ e $5^{\circ}$ Anos dos Liceus ${ }^{(19)}$, «os judeus» só são alvo de atenção aquando da referência à criação das Inquisições espanhola e portuguesa (Capítulo «Expulsão dos judeus»). Uma vez mais, tanto a «violência popular» como a «intervenção punitiva» das instituições são apresentadas como decorrendo «das características e ações inaceitáveis dos israelitas».

Depois de invocar as «revoltas populares e as chacinas» que se teriam repetido ao longo da Idade Média enquanto «resposta caótica» às «ofensas perpetradas pelos israelitas», António G. Mattoso afirma que em

1491 foram condenados à morte vários judeus, que haviam sacrificado uma criança cristã, em simulacro da paixão de Cristo. E embora as comunidades judaicas censurassem tais actos de fanatismo, a verdade é que o povo, convencido de que aquela «morte ritual» era prática corrente entre os judeus, exigia castigos severos contra a sua raça. Os Reis Católicos resolveram a questão, ordenando a sua expulsão, por Decreto de 31 de Março de 1492.

Deviam partir no prazo de 3 meses todos os que não se baptizassem, com seus filhos, criados e familiares; podiam alienar os seus bens, mas eralhes proibido transportar ouro ou prata. Segundo os melhores cálculos, deixaram a Espanha 165000 judeus, que partiram para África, Itália, Grécia, Turquia, etc. Os de Castela e da Estremadura fixaram-se, na sua maioria, em Portugal, onde foram acolhidos por D. João II, mediante o pagamento de um tributo. Mas pouco tempo aqui permaneceram, visto D. Manuel ter ordenado a sua expulsão em 15 de Novembro de 1496. De Navarra, que ainda estava fora da unidade hispânica, só saíram em 1508. (p. 291/292)

Escrita e divulgada, no seguimento de António Sardinha e Alfredo Pimenta, enquanto contributo para a consolidação da hegemonia intelectual do Estado Novo, a História de Portugal de João Ameal é uma obra de divulgação da memória histórica do salazarismo ${ }^{(20)}$. De novo, as referências «aos judeus» ocorrem, apenas, em ligação com os reinados de D. Manuel I e de D. João III. Sendo a população portuguesa "predominantemente de origem lusitana», "cartagineses,

(19) Cf. António G. Mattoso, Compêndio de História Universal ( $4^{\circ}$ e $5^{\circ}$ Anos dos Liceus), Lisboa, Sá da Costa Editora, 1939.

(20) Cf. João Ameal, História de Portugal, Porto, Livraria Tavares Martins, 1940. 
romanos, bárbaros, árabes e berberes, judeus, normandos, negros, etc.» constituiriam minorias pouco significativas ou «comunidades hostis». No final do século $\mathrm{XV}$, o avolumar da «ameaça judaica» teria exigido uma intervenção global e definitiva por parte «do Estado, da Igreja Católica e do povo».

Nas palavras de João Ameal, somos

os últimos a lançar mão de tão radicais providências. E, no entanto, o fermento de ódio ao parasitismo hebraico, persistente no nosso povo, reclama acção pronta por parte do poder, a fim de solucionar a questão [...]. Quanto aos benefícios da Inquisição, esses são evidentes e incontestáveis: livra-nos das terríveis guerras de Religião que assolaram o centro da Europa e as Ilhas Britânicas; sobrepõe a justiça e o prestígio do Estado às caóticas e bárbaras represálias populares; desintegra o núcleo hebraico, ameaçador da unidade nacional; zela eficazmente pela observância dos preceitos da Fé e das regras da moral. Bem haja D. João III pelo empenho que mostra em nos dar a Inquisição e por conseguir, com o êxito das suas diligências, ministrar à sociedade portuguesa o antídoto eficaz contra os venenos do luteranismo e contra os abusos de Israel. (p. 300 e 305/306)

\section{Por sua vez,}

do lado do elemento semita, multiplicam-se insolências e desafios que contribuem para envenenar os ânimos [...]. Poder-se-iam mencionar grande número de episódios que mostram os judeus na sua tarefa de provocadores, de insultadores das crenças e símbolos católicos. Resultado: em muitos casos, a gente miúda, desvairada pela cólera, entrega-se a violentas represálias. O que é preferível? Deixar o povo fazer justiça ou injustiça - por suas mãos (como nas horríveis jornadas de 1506) ou confiar tal missão a um tribunal idóneo, ligado à Coroa, que intervirá na escolha dos juízes? (p. 300)

Diretor do Instituto de Anatomia da Faculdade de Medicina da Universidade do Porto, Joaquim Alberto Pires de Lima publicou em 1940 Mouros, Judeus e Negros na história de Portugal(21). Tratar-se-ia de um

(21) Cf. Joaquim Alberto Pires de Lima, Mouros, Judeus e Negros na história de Portugal, Porto, Livraria Civilização, 1940. 
«contributo para a comemoração do VIII Centenário do nascimento do Reino de Portugal»e, mais especificamente, para a preparação do Congresso Nacional de Ciências da População. Apoia, na referida obra, a perspetiva segundo a qual «a raça portuguesa» derivaria «dos Celtiberos, Romanos, Germânicos, Judeus, Mouros e Negros», sendo os três primeiros contributos decisivos e os três últimos «povos intrusos». Afirma, ainda,

que o nosso povo vê sempre de soslaio os elementos estranhos, desconfiando dos Mouros, odiando os Judeus, a cuja raça não perdoa a Paixão de Cristo nem a exploração usurária, e mostrando às vezes certa simpatia pelos Negros, apesar da sua maior inferioridade étnica [...]. (p. 14)

No resto da Europa e na América contemporâneas, os

Judeus não se dedicam à agricultura, nem à vida militar. Mas têm nas suas mãos os bancos, onde se acumula o capital; são deles as fábricas de material de guerra; têm por si a opinião pública, pois que a dirigem e subjugam por meio da imprensa; ocupam cátedras universitárias, sobem à tribuna como representantes do povo e sobraçam pastas de ministro legislam, governam, dominam. (p. 35)

Em Portugal, ao longo da Idade Média, os

Judeus nunca foram lavradores, nem marinheiros, nem soldados, mas viviam alimentando-se do trabalho alheio. Eram mercadores, médicos, boticários, clérigos advogados, escrivães. Os médicos e farmacêuticos eram acusados de matar legalmente os inimigos cristãos, que, por outro lado, eram explorados e roubados pelos Judeus das outras profissões. (p. 46)

Sob a forma de «conclusão moralizante», invoca Joaquim Pires de Lima que, em

Bragança e na Beira Baixa, onde abundavam os Cristãos Novos, persiste ainda a tradição dos afogadores ou abafadores, Judeus que tinham por missão estrangular os seus irmãos em crença, quando moribundos. Parece que não se tratava de práticas de eutanásia, mas sim de impedir que os doentes denunciassem, na hora da morte, os seus correligionários. Se não fosse a resistência tenaz dos Cristãos e a brutal defesa de que usaram, tudo leva a crer que os Judeus, com 
a sua vitalidade de raça prolífica e a fé inabalável nos seus destinos, transformassem a Península numa colónia de Israel. (p. 45)

Escrito em 1943 e publicado em 1944, dois dos anos durante os quais ocorreu a Segunda Guerra Mundial e o Holocausto, em Rumos da arte portuguesa ${ }^{(22)}$ Fernando de Pamplona associa inequivocamente «os judeus», «a arte moderna» e a degradação intencional, quer da «Civilização Ocidental» em geral, quer da «arte portuguesa» em particular. Comparados com «os filhos da África negra», «os israelitas» patenteariam as suas «raízes orientais» e uma pretendida incapacidade de produção estética figurativa:

Não há que iludir-nos! É a invasão da arte europeia pelo Oriente brumoso e pela África negra - o primeiro quase órfão de tradições plásticas, a segunda a debater-se em plena selvajaria. É a sorrateira infiltração dos novos bárbaros, dos criadores de monstros, que proliferam como gafanhotos... (p. 79)

Segundo o autor, compreende-se

que uma raça de iconoclastas, dada à abstracção nebulosa e a especulações confusas, traga no sangue a incompreensão e o horror da curva harmoniosa, apta como nenhuma outra a representar os corpos vivos, e que, ao tentar esta representação, difícil entre todas, procure grosseiramente esquematizar e deformar, resvalando num geometrismo sumário e ou numa visão caricatural. Outra característica oriental, e esta eminentemente judaica: o hermetismo, que vai do Talmude ao «Apocalipse». Ora a maioria dos expressionistas, cubistas, sobrerrealistas são de proveniência oriental, judeus ou discípulos de judeus. (p. 67)

Negando quaisquer "preconceitos injustificados», Fernando de Pamplona proclama:

Apenas registamos a sua [dos judeus] inferioridade manifesta no domínio das artes plásticas e portanto a sua rotunda incompetência para, neste particular, darem lições aos europeus, que, através de mais de dois milénios, plasmaram obras primas sem conta e sem par. Apenas

(22) Cf. Fernando de Pamplona, Rumos da arte portuguesa, Porto, Portucalense Editora, 1944. 
verificamos objectivamente (e nada temos a fazer-lhes...) que um abismo os separa da tradição europeia e do seu espírito e que representam a negação intolerável e brutal de tudo quanto temos sido e somos, de tudo quanto conquistámos e amamos. Submetermo-nos a estes estrangeiros do interior, a estes bárbaros da sensibilidade equivale a demitirmo-nos. A Europa estará madura para a servidão? (p. 70/71)

\section{Conclusão}

Argumentei, neste texto, sobre as características totalitárias e fascistas do Estado Novo português, acerca da compatibilidade entre a natureza do salazarismo e um discurso propagandístico na aparência moderado, com muitas semelhanças face aos períodos anteriores (Monarquia Constitucional, Primeira República e Ditadura Militar). A ditadura teria procurado concretizar uma estratégia de propaganda ao mesmo tempo sistémica e controlada, preventiva e mobilizadora mas diferenciadora de diferentes segmentos da população (elites, classes médias e classes populares; ativos e absentistas em termos cívicos), absolutamente condenatória das alternativas e fundamentadora do regime/ do seu Chefe.

Afirmei que o Estado Novo encontrou na relação com «o passado» um dos seus principais vetores de legitimação, que configurou e tentou impor o historicismo neo-metódico como a leitura oficiosa acerca da «história pátria», que optou por construir uma «identidade nacional» e por se apresentar como legítimo continuador da mesma. Recorreu a antigas e a modernas modalidades de condicionamento do processo de reprodução da memória histórica, com destaque para o ensino e as «comemorações histórico-patrióticas», o património cultural e a museologia, a arquitetura e o urbanismo, a comunicação social e a atividade de organizações de enquadramento de massas.

Concordando com os investigadores que classificam o salazarismo como regime que não promoveu soluções radicais de discriminação dos e de perseguição aos judeus, discordei da avaliação segundo a qual Portugal teria desconhecido, na primeira metade do século XX, formas significativas de darwinismo social e de antissemitismo. Referimos, a este propósito, a reafirmação da natureza «estrangeira e negativa», para a «Nação Lusa» e, em geral, para a «Civilização Ocidental», da religião 
e da cultura judaicas, bem como o sistemático louvor do antijudaísmo verificado na Época Moderna; o argumentário invocado e medidas político-administrativas adotadas, contra os refugiados de origem judaica, na segunda metade da década de 1930 e durante o período da Segunda Guerra Mundial/do Holocausto.

Tentei, igualmente, rastrear e interpretar, de forma contextualizada, exemplos avulso de modalidades de construção de memória histórica - da mundividência oficial ou oficiosa do Estado Novo - nos quais o antissemitismo desempenhasse uma função relevante ou, mesmo, nuclear. Coerentemente com a estratégia de mobilização contida adotada pelo salazarismo, observou-se uma focalização maioritária nos períodos medieval e moderno. A quase ausência de referências à Época Contemporânea resultaria do facto de Portugal ter resolvido o seu «problema judaico» nos séculos XVI a XVIII.

No fim do presente artigo, chamo a atenção para as dificuldades de interpretação da realidade portuguesa (e de outros objetos de estudo) que decorrem de uma utilização redutora dos conceitos de antijudaísmo e de antissemitismo. Talvez se justifique deixar de pressupor que existe uma distância inultrapassável entre a primeira categoria - supostamente válida para os períodos medieval e moderno, bem como para a generalidade dos setores católicos na época contemporânea - e a segunda, aplicável somente ao período contemporâneo (e, neste, antes de mais, aos cultores das várias modalidades de darwinismo social).

À semelhança do ocorrido nos séculos XIX e XX, também na época moderna, para além da condenação da crença na religião judaica e da prática de outros rituais da cultura em causa, da atribuição aos indivíduos que recusam converter-se ao cristianismo de lacunas morais e de objetivos malignos limitados, houve quem considerasse que «os judeus» - os seus corpos e almas deformados - não eram recuperáveis e tendiam necessariamente à concretização de conspirações globais. Daí que o Tribunal do Santo Ofício assegurasse, quer a investigação de ideias e de práticas judaizantes, quer a emissão dos «atestados de limpeza de sangue», garantes da segregação e da hierarquização entre "cristãos velhos» e «cristãos novos».

Eventualmente, as principais diferenças estarão, não nos vetores nucleares de ambas as posturas condenatórias de judeus - o antijudaísmo e o antissemitismo -, mas nas características estruturantes das sociedades de Antigo Regime e das economias-mundo contemporâneas. 
Segmentados (em termos sociojurídicos e geográficos), fundados na ligação entre política e religião, mais fechados sobre si mesmos, os Estados da época moderna geraram mundividências parcelares e focalizadas em indicadores religiosos. Integradas, laicizadas e mais internacionalizadas, marcadas pela afirmação do(s) cientismo(s), as sociedades da idade contemporânea construíram ideologias sistémicas e baseadas em fatores rácicos ou genéticos. 